\title{
Quarter Kilogram
}

National Cancer Institute

\section{Source}

National Cancer Institute. Quarter Kilogram. NCI Thesaurus. Code C69117.

A unit of mass equal to $1 / 4$ kilogram, or 250 grams. 